569 TLC Keynote: Democracy is More Important than a P-Value

575 TLC 2020 Track Summaries

593 American Political Science Review Editors' Report 2018-20

603 Perspectives on Politics Editors' Report 2018-19

608 The EPA and Federalism: A Pracademic Perspective
612 Congressional Fellowship Program Updates

6132020 APSA Council and Officer Nominees

617 Meet the 2020 Bunche Fellows

621 Minutes of August 2019 Council Meeting

6262019 Dissertation List

6372020 Annual Meeting Information

\title{
TLC Keynote: Democracy is More Important Than a P-Value: Embracing Political Science's Civic Mission through Intersectional Engaged
} Learning

\author{
Lori M. Poloni-Staudinger, Northern Arizona University \\ J. Cherie Strachan, Central Michigan University
}

\section{INTRODUCTION AND \\ ACKNOWLEDGEMENTS}

Hello. Thank you, Steve and Paula, for the introduction. We want to thank Shane and Sara for asking us to be here. Special thanks as well to Tanya and her team and everyone at APSA. Finally, we would be remiss if we didn't mention Mike Wolf who is in the audience today. Mike introduced us to each other about a decade ago, and it has been a match made in heaven ever since. If you like what we say today, you can thank Mike. If you don't, you can blame him.

\section{REPRIORITIZING OUR CIVIC MISSION}

Today we want to talk to you about democracy and embracing the civic engagement mission of our discipline. You'll notice that the title of our talk is inherently provocative. Democracy is more than a p-value. We know that we can embrace the science in political science while still keeping in sight our core mission to educate our next generation of citizens. So, we are purposefully setting up a bit of a straw woman here to force us to confront what we see as a creeping problem in our discipline. Namely, we have gone too far in pursuit of the newest method or the most complicated equation, and sometimes we lose sight of what we argue ought to be the fundamental core of our discipline: embracing the civic mission of political science. From what APSA funds, to what our top journals publish, to what we look for in the hottest new candidates
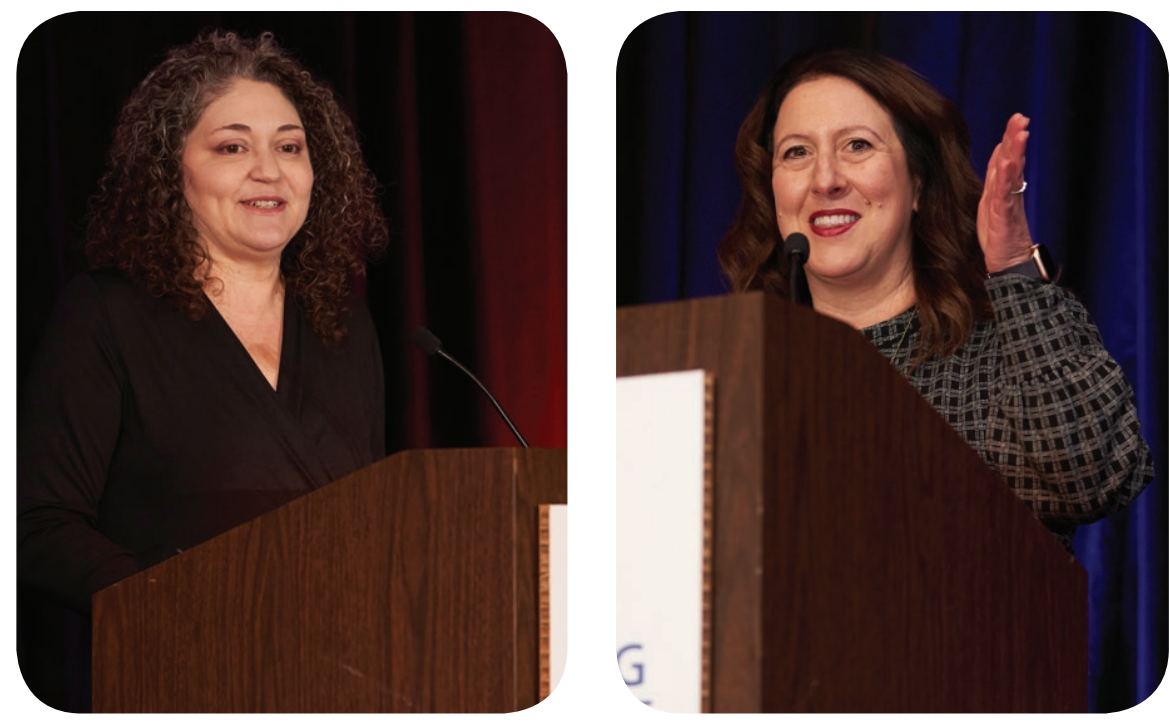

Above: J. Cherie Strachan (left) and Lori M. Poloni-Staudinger (right) deliver the TLC 2020 Keynote Address.

on the market, we argue that the pendulum has swung too far away from this core value and it is time to swing back. We hope that what we can talk about today is how we can do better. How can we embrace the civic engagement mission of political science, and how can we work in our classrooms, in our communities and in our discipline to advance this mission?

There is no better time for us to have this conversation. By many accounts, democracy is in trouble. Studies show a decrease in support for democratic institutions across advanced industrial democracies, and this decrease in support for democracy is stronger among younger generations than older. For example, only $30 \%$ of American millennials say that it is important to live in a democracy compared to $75 \%$ of people born before 1930. In fact, in a 2010 poll, fully $24 \%$ of younger Americans said that democracy was a bad form of government (Foa and Mounk 2017). The trend has not improved in the last decade. This is not a phenomenon unique to the United States. Researchers have found a similar cohort pattern across all longstanding democracies, "with the proportion of younger citizens who believe it is essential to live in a democracy falling to a minority" (Foa and Mounk 2017). Recently published data shows that across the globe, $58 \%$ of respondents are 
dissatisfied with democracy as a form of government (Mounk and Foa 2020). This statistic mirrors a concomitant decrease in trust among younger generations as well (Poloni-Staudinger and Wolf 2019).This evidence alone should give all of us pause and make us stop and reflect for a moment about what we are doing in our classrooms and communities to ameliorate this issue.

Why do we feel so strongly about this? Because like Winston Churchill, we believe that democracy is the worst form of government, except for all the others.

You'll notice that the part of our title we haven't addressed yet is this idea of intersectional engaged learning. It isn't enough that we re-embrace the civic mission of political science if this does not apply to all our students and all our communities. We need to be mindful that what we teach and how we teach has implications not only for the health of our democracy but for who engages in politics in the future and how they choose to engage. What we do in our public spaces, including our classrooms, signals who belongs at the table and who is not welcome. In a recent edition of Liberal Education published by the Association of American Colleges and Universities, Cathy Davidson, a distinguished professor at CUNY, reminds us that all our theorizing about equality hasn't changed our actual profession (Davidson 2019). We can't alter structural inequalities simply with good words-we have to build structures that put equality at the core. When we engage with students, we are passing on a value system as well as implicit bias, and it is important that we keep this at the forefront of our minds.

Given declining opportunities for civic and political socialization in natural settings like the public sphere and civic organizations, it is incumbent upon each of us to embed civic engagement pedagogies in our classrooms, in our institutions, in our professional organizations and in our communities. This means, we need to engage in conversations about best practices around active citizenship, democratic decision making and political leadership.

This also means we need to walk the walk. Eitan Hersh wrote recently in The Atlantic about the rise of the political hobbyist (Hersh 2019). This is a college-educated individual who reads a lot about politics, can recount in detail the latest political or social issue, like the Warren-Sanders electability question, but does not really participate in any real way in the system outside of voting. In this piece, based on his book Politics is for Power, Dr. Hersh tells the story of a woman named Querys Matias. Matias is a 63-year-old immigrant from the Dominican Republic. She lives in Haverhill, Massachusetts, a small city on the New Hampshire border. Her paid work is as a bus monitor for a special-needs school. Matias is also a leader of a group called the Latino Coalition in Haverhill, bringing together the Dominicans, Puerto Ricans, and Central Americans who together make up about $20 \%$ of the residents of the city. The coalition gets out the vote during elections, but also meets with elected officials, pushes for dual language access to political power and has been instrumental on moving the dial on several pieces of public policy.

How many among our discipline are political hobbyists? Yes, maybe our methods are fancier and we read peer-reviewed journals in addition to the Washington Post, but are we really that different from the armchair "political scientist" reading the latest New York Times or Monkey Cage without ever practically engaging in our political process? We ask you to think if the majority of those in our discipline are modeling what it means to be an engaged citizen, or are simply studying it? What would it mean to use Querys Matias as a role model, and to truly embrace our civic engagement mission and embed intersectional engaged learning into all aspects of our discipline?

\section{POLITICAL SCIENCE'S ROLE IN CIVIC ENGAGEMENT'S NEXT WAVE}

It is important to note, as we encourage the discipline to embrace intersectional engaged learning and to play a bigger role in the next wave of the civic engagement movement, that we are not starting from scratch. We need to recognize those who paved the way. Because of them, we have broad shoulders of colleagues-colleagues who have been active members of the political science education section, many of whom are here this afternoon-to stand on. So, it is important to note that the discipline of political science was there in the 1980 , when scholars and administrators first noted concern that our students were less engaged in public life-and launched the service learning and community engagement movement to address those concerns. Political scientists were there, again, a decade later when we realized that this emphasis on voluntarism had not led to increased political participation among our students but had in fact provided many of them with an excuse not to participate in politics. In response, political scientists helped transition from this focus on service learning and community or civic voluntarism to the political engagement or democratic engagement movement. Hence the current version of these efforts to re-engage our students in public life is focused on student voter registration and turnout.

Yet participation in all these efforts, from promoting service learning to more explicitly promoting political participation, has always occurred on the periphery of our discipline. Indeed, outside of this roomor at least beyond the type of faculty who typically attend APSA's Teaching \& Learning Conference-it would not surprise us to learn that many political scientists have not heard of the civic or political engagement movement in higher education, or to learn that they do not really understand what it is. Hence, we argue that political scientists must step up. We argue that, for the sake of our students and the sake of democracy, political scientists should play a central role in the next wave of the civic and political engagement movement. Further, we believe political scientists must play this role for three reasons.

The first of these is that, as in the title of the book we just mentioned, political scientists understand, better than scholars in any other discipline, that Politics is for Power. We know that the social ills and public issues that our students are dedicated to addressing through voluntarism will never truly be solved until they also wield the power of the policy-making process. Who better to carry this message, not only to our students, but to our colleagues in educational leadership, as well as to student affairs staff in our campus volunteer centers, who are now positioned at the center of the community and civic engagement movement? Who better than us to normalize wanting to wield such power-and to convey to others and to our students that it is acceptable, and in fact a good thing, to want to influence public policy making? So, the first reason political scientists should be at the forefront of a reinvigorated engagement movement on our campuses is that we are the ones who truly understand that politics is about power.

The second reason is that political scientists understand that metrics, or the number of activities students participate in on campus, are not engagement. More so than scholars from any other discipline, 
political scientists understand that lifelong participation in public life requires the cultivation of civic identity. Others on our campuses may be confused by the term engagement, equating it with the performance of activities. Rather than focusing on cultivation of civic identity, they often focus on counting how many students show up to events, how many volunteer hours our students have logged, or more recently how many have registered and voted in elections. But political scientists know that the term engagement refers to psychological engagement, because sustained participation in the type of activities just described, after students graduate and leave our campuses, requires intrinsic civic identity.

Hence as we noted, it is important that political scientists more widely embrace being active, engaged citizens as part of our own identity. For the only way we convey the importance of this identity to our students is if we internalize and embrace it ourselves. We need to convince our students that when they come to campus, they are being invited to join not just a community of scholars-but a community of public-spirited scholars who take both our commitment to rigorous scholarship and our commitment to public life seriously. If our students lack exposure to this type of robust political socialization, they will not come to think of themselves as public-spirited or engaged citizens, and they will not be motivated to close the gap in civic and political participation that affects younger generations. But, if we can change the way they think of themselves, changes in their behavior will inevitably follow. Political scientists understand this connection, and we intuitively know that engaged learning ultimately needs to be about cultivating our students' civic identities.

Even political scientists who understand the importance of intrinsic identity, however, often feel intimidated by the task of achieving this outcome with our own students. Yet we guarantee you that the task is not as difficult as some make it out to be. In fact, as authority figures, faculty engage in socialization to cultivate intrinsic identities all the time-by simply making it clear who we expect our students to be and holding them accountable for performance of behavior linked to those roles.

We swear, it's not rocket science. To illustrate this point, we can turn to a simple example not from academia or teachingbut from parenting. When one of our sons was young, he asked for drum lessons. This request made his father, who is a musiclover, very happy-and he proceeded to purchase a rather expensive drum kit. As a result, the son was told, "Oh, you aren't just going to take drum lessons, you are going to be a drummer!" After joining a School of Rock program, where he performed in a band with other kids, the son pulled out his metronome and practiced regularly, without being asked. He was motivated to prepare for those performances with his band, because he had internalized the identity of "a drummer," and that's just what drummers do. Cultivating identity can be as simple as that. We just need to adopt the same approach when we encourage our students to become engaged citizens. We simply need to make it clear that we expect them to perform as engaged citizens, and they need to do so not at some later stage in their lives when they become "adults," but now while they are still on campus. And we make sure to give them the opportunity to practice. We aren't starting from scratch as we start to think about creating similar types of "performances" that prepare students for political engagement, where we create learning experiences that make it clear we already think of them as citizens. Many of our colleagues here have contributed articles about civic and political engagement to the Journal of Political Science Education-as well as to the two edited collections published by the American Political Science Association-which provide a wealth of examples, both in smallscale ways that scaffold civic skills in the classroom to more immersive applied learning experiences, in campus life or internships or simulations (Bennion et al. 2013; Bennion et al. 2017). These are all designed to promote intrinsic civic identity and the lifelong political engagement that will accompany it.

And of course, we have the insights provided by the Carnegie Foundation for the Advancement of Teaching's (CFAT's) Political Engagement Project (PEP) which relied on multi-campus research to learn that the best practices for promoting political engagement include opportunities to participate in politically-active communities where students practice civic and political skills and engage in discussion of political issues in racially- and ethnicallydiverse settings (Colby et al. 2007).

And this leads us to the third reason why it is so unfortunate that political science has been at the periphery of the civic engagement movement and why we need to play a more central role. This is because we have so many insights to offer into the type of learning experiences students need to become engaged citizens, and, in particular, about why effective civic and political engagement must be intersectional. Up until now, the civic engagement movement has, for the most part, attempted to identify universal best practices that, if simply implemented in a blanketed fashion across all our campuses, would be effective in turning our students into citizens. Yet who better than political scientists to recognize that demographic groups will react differently to political stimuli-including political learning-in different ways? Who better to hold up a finger and to say, "oh, but lived experiences matter!" Can any one of you imagine trying to publish political behavior research without including a full array of demographic identities as controls? What would you do to that piece as a reviewer? You know you would turn into Reviewer \#2, and that you would shred it! Because we know that people's lived experiences, based on their race, ethnicity, sex, orientation, religion, and so on will affect their reactions. And that, we believe, is the next step those of us committed to civic engagement pedagogy must take, crafting effective civic and political learning for all our students, and not just those already inclined or encouraged to participate in politics.

\section{INTERSECTIONAL CIVIC ENGAGEMENT IN PRACTICE}

So, what might this approach-this intersectional civic engagement pedagogy we keep talking about-look like? Again, it's not rocket science. It simply requires taking insights gleaned from our own scholarship and applying it to our teaching. What follows are some examples of intersectional approaches that we and others in our discipline have been working on.

The first example we want to share comes from a Consortium ${ }^{1}$ project on rude politics and college student engagement that Cherie undertook with Elizabeth Bennion (Indiana University, South Bend), Monica Schneider (Miami University), and Angie Bos (College of Wooster). Together, they conducted an online experimental design on 18 campuses, with about $65^{\circ}$ students enrolled in political science classes participating. Students were randomly assigned to view clips of rude or civil political interactions and to answer a post-test about how those interactions affected their attitudes toward participation. The major 
finding was that almost all students were alienated by rude politics-which they all thought was typical (Schneider et al. 2020). This means that we need to re-think the skills required to participate in politics. All students need help learning how to respond to rude and aggressive political figures in order to feel comfortable jumping in.

But of course, that isn't the entire story. Students who scored high on interest in wielding power-who also happened to be overwhelmingly men-might not like rude politics, but they were willing to learn how to do it, in order to gain power. And those who scored low on interest in power-who were more likely to be women-were particularly alienated. What this means is that if we don't want politics to become even more gendered and if we don't want to exacerbate the masculine ethos of politics, we need to focus on helping students develop a thicker skin, to learn to take a hit, and to worry less about being liked when they step into the political lime-light. One example of a tactic that might work that we highlight in our new book, Why Don't Women Rule the World, is "Name It, Shame It, Pivot" (Strachan et al. 2019). So, when a woman is targeted with a sexist attack, we have them practice saying "that was a sexist thing to say, and I don't want those kinds of comments to detract from the real reason I'm running for office, which is this issue, and here's why I'm the best candidate to solve that issue."

Yet another demographic difference we found in this research is that women of color also responded to rude politics with a sharp spike in political ambition, not because they have high interest in power, but because they feel a deep civic obligation to fix what is wrong with the political system (Schneider et al. 2020). If you read our own literature such as books by Patricia Hill Collins or Melissa Harris Perry's Sister Citizen, this response makes complete sense (Collins 2000; 2004; Harris Perry 2011). The deep history of hardship but also of self-reliance, combined with socialization in social justice movements, makes African American and Latinx women particularly apt to respond this way. In qualitative research that explores this type of political motivation, one woman told an interviewer, "Who better to do it than me?" (Frederick 2014). And yet, these women seek political power through community organizing and movement politics, and might need to be convinced that those activities qualify them for public office. This means our discipline needs to do a much better job of teaching about disruptive politics and normalizing alternative pathways to power. If we don't, these women, the kind of women who founded Black Lives Matter and women like Querys Matias who step up to fight for policies every day in their local communities, aren't going to stick with political science. They will take Intro to American Government and then abandon us for disciplines like sociology, and we will lose the opportunity to train a more diverse array of students for explicitly political leadership.

We can draw another example from civic engagement's reliance on deliberative pedagogy. An array of scholars, from Anne Beaumont's work with the Political Engagement Project to David Campbell's work in Why We Vote to Diana Hess and Paula McAvoy's research on k-12 classrooms, emphasize the importance of deliberation (Beaumont 2013; Campbell 2010; Hess and McAvoy 2015). Discussion of controversial political issues in a safe classroom setting in terms of in-class learning provides the most bang for your buck, for promoting long-term, consistent political participation across adulthood. Scholars think this happens not simply because such conversations build political interest and awareness of current events, but because peer expectations shape intrinsic civic identity and that drives participation over the decades.

But guess what? Deliberative pedagogy isn't so great for everyone, and if we look to the critics of deliberative democracy theory from the 1990 s and early 2000 , scholars like Iris Marion Young or Lynn Sanders, we shouldn't be surprised that deliberative pedagogy works really well for white men, who feel comfortable and aren't judged or subject to social sanction when they express political opinions, but not so well for women and minorities (Marion Young 200o). Again, rather than throwing the baby out with the bathwater, we should look to our own discipline's literature for how to fix deliberative pedagogy to make it work better for everyone. Christopher Karpowitz and Tali Mendelberg had a great book about deliberative forums a few years ago titled The Silent Sex (Karpowitz and Mendelberg 2014). They found that forum rules make a huge difference. If you want women and minorities to participate, for example, you can't rely on simple majority votes. You should use super-majority votes or consensus building to reach decisions because those rules mean women and minorities can't be ignored or talked over. Another tactic, if you can manage it, is to assign groups where women are close to half of the members because then conversation norms are more apt to promote facilitation and listening, and less apt to promote argument and interruption, which again makes it easier for them to participate. Another option could be to teach all students parliamentary procedure and require them to use it. This is because parliamentary procedure enforces norms of civility like no interrupting, waiting to be recognized, limiting speaking time and turns and makes it easier for women and minorities to gain the floor and to participate without being judged. We just need to use the insights from our own discipline's research to make sure we design civic engagement pedagogy that works for everyone (Strachan 2017).

A third example comes from another Consortium project-the National Survey of Student Leaders, which Cherie undertook with Elizabeth Bennion. We were interested in civic learning that takes place in student organizations, so we sent a questionnaire to the presidents of registered student organizations on over 30 campuses across the United States. We found major differences in how different types of students responded. One of the most interesting findings was that Greek organizations provided by far the best opportunity to hone a wide array of civic and political skills. And fraternity presidents overwhelmingly recognized that they could transfer these skills to achieve political influence. Despite having the same robust civic learning, however, sorority presidents were less likely than not only fraternity presidents, but than all other types of presidents, to anticipate using their skills to achieve political influence. Hence women's self-selection into groups that embrace traditional gender roles overrides civic learning. That is an outcome that political scientists should care about and should try to help resolve (Strachan and Senter 2013).We also found that first-generation students were far less likely to wind up in leadership positions at all, likely just not realizing how important such activities are. On most campuses the percentage of first-generation students in the student body far out-paced the percentage who served in leadership positions. One of our participating campuses found this effect for first generation Latinx students and then worked with their diversity office to create more clear pathways to leadership positions for those students, fixing the issue. Sometimes intersectional civic engagement 
pedagogy is just a quick fix after paying attention to the ways our students experience college differently. It doesn't always have to be hard or a major initiative.

But sometimes it should it be a major initiative. We argue that when we teach classes about marginalized groups (women, ethnic or racial groups, LGBTQ+ people, and so on) that are likely to attract students from those groups-it is important to incorporate civic engagement pedagogy designed to be effective for them. That sentiment was part of the inspiration for our new textbook, Why Don't Women Rule the World? (Sage/ CQ Press), co-authored with our colleagues Shannon Jenkins (University of Massachusetts, Dartmouth) and Candice Ortbals (Pepperdine University).

Research from our own discipline tells us-and has told us - that aside from voting, women have lower levels of political participation and ambition than men. This is a major feature of the substantive knowledge taught in women and politics courses. But that same literature reveals the type of experiences that bolster women's efficacy, interest, and ambition. So, as we were talking about the book, we said: why isn't anyone using those insights to create activities that replicate such important experiences? And our discipline's own research findings provided the basis for ambition activities that we embedded at the end of every chapter.

We know that women need to be asked several times to run for office and that they need to be encouraged to view their experiences as relevant. One activity requires students to pair off, conduct an interviewand to write one another encouraging letters.

We know that women are more likely to run when they extend care giving and nurturing into public policy. So, we also ask women to consider all the people affected by issues that they care about and to think how many they could help if they were the ones with the power to draft relevant public policies.

We know that women's ideas are often appropriated by others in deliberative settings-so we ask them to practice a tactic developed by women in the Obama White House called "amplify"-where they agree to work as a team, to call out and give credit to other women, when their ideas are re-stated by men.

We know that women in the public sphere will inevitably face sexism and misogyny, so we teach them the Name-It,
Shame-It, Pivot tactic described above. But we also have a reflective activity that prevents less overt micro-aggressions from taking root and transforming into imposter syndrome.

We could go on with examples from our own text or from other people's teaching and projects, but think you have the idea now. Overall, we are grateful to those who launched the civic engagement movement and gave us shoulders to stand on. And we believe the best way to build on this foundation is to focus on intersectionality, so that we don't leave any of our students behind. Given political science's careful attention to the effects of demographic identities in our scholarship, we think that our discipline has a great deal to offer the broader civic and political engagement movement, as we take this next essential step.

\section{BRINGING BALANCE TO OUR DISCIPLINE}

For our discipline to truly embrace our mission of civic education, we need to offer up some tough love. Sorry APSA, but this is what we call the Fried Green Tomatoes part of the talk; it may be a little irreverent, but to paraphrase Kathy Bates, we have job security and good insurance.

If we truly care about good governance, then as political scientists we need to ourselves engage. For some of you, we are preaching to the choir. For others, or for our discipline writ large, this is something we need to talk about. We need to not only incorporate an engaged pedagogy in our classrooms, we need to model what it is to be an engaged citizen in our communities, in our country and in our world. Just as a medical doctor would be negligent in seeing a person who was sick and not suggesting medical treatment, we commit malpractice if as political scientists we look at a world in fracture, a country sliding away from democratic ideals, and a climate in crisis but choose not to act. We have gone too far in the direction of chasing the "science" in political science, that we have neglected the political part of our discipline. We have slowly become the hobbyists we bemoan who are negatively impacting our system of government.

Expanding this approach to teaching, however, means grappling with why political science has prioritized cultivating academic "hobbyists" over cultivating engaged citizens. We know that the discipline of political science emerged in response to the Progressive Movement.
Scholars, and in particular historians, launched a new discipline precisely because they wanted to not only study the political process, but because they wanted to make recommendations that would be taken seriously and would be used to improve democratic governance. In short, our discipline emerged with an overtly normative agenda. Early political scientists realized, however, that our recommendations would not be taken seriously by politicians and policy makers unless we established ourselves as a respected social science. So initially, adopting rigorous and cutting-edge social science methods was a means to a normative end.

Over time, the means became the end. So much so that in graduate school, we are socialized to reject any whiff of a normative agenda. So much so that our discipline spends inordinately more time, arguing about which method is the most rigorous and which one new approach will (finally) solidify our status as a respected social science in academia than it does worrying about if our students are engaged citizens. In short, we are out of balance, hyperfocused with being scholarly at the expense of being public-spirited.

Those of us who are truly intellectually curious know that we gain the most insight through triangulation. Every method of data collection has strengths and weaknesses, and we learn the most when scholarship from a wide array of methodological approaches reinforces the same conclusions. So why do really smart people in our discipline spend so much time fighting over which method is the best, or the only scientific one? They do so because by establishing themselves as experts in the only "truly" scientific method, they stand to garner substantial status within the discipline such as the ability to recruit the best graduate students, control access to the top-ranked journals, win elections to APSA Council, and receive the bulk of grant monies. Everything in academia, and in the way our discipline is currently structured, encourages artificial arguments about who among us are the most rigorous scientists, while discouraging concern for our students' democratic capacity.

And of course, we would be remiss if we didn't mention the way in which classism and sexism reinforce these choices. This is because civic education is seen as something that, largely, women and k-12 social studies teachers do, while male political scientists are scholars who prioritize their research. 
We need to change our perspective. We need to celebrate those among us who are teacher-scholars. The work you are doing is more important than a journal publication with a fancy equation using the latest open source program. You are educating our next generation of leaders. This work should be highlighted in our top journals. This work should be funded by our discipline, and this work should be elevated in discussion.

Lori was on a flight recently and in the row behind her was a retired marine. The flight attendant stopped everything, had her section of the plane thank him for his service and gave him free drinks. In no way do we want what we say next to be seen as a denigration of that marine's service, but this experience makes one think.

The work that you do in your classrooms to advance the cause of democracy, to teach our next generation of leaders and to enhance civic skills among our citizens should be celebrated like travelers celebrated that marine's service. In our ideal world, we thank the political science professor for the service they do in training the next generation of public-minded leaders. While we're not going to buy you all drinks, we want to thank all of you for your service.

It is unconscionable that in 2020, the political ambition of our female students still lags behind that of their male counterparts. We want to stop for a moment and ask all of you to think about what you are all doing in our classrooms, in our communities, in our departments to ensure that this changes. In 2030 is it going to be the same story? Or will two of our students be up here standing before you giving the TLC 2030 keynote to tell you that women's political ambition in universities surpasses that of their male peers?

\section{CONCLUDING CALL TO ARMS}

So, this is a call to arms of sorts. We can all do more to embrace the civic mission of our discipline. We can all be better role models. For some of us, this may be taking up a voter registration drive on campus. For others, we may be incorporating the type of ambition activities discussed earlier. We may ask our students to practice deflecting microaggressions and to name, shame and pivot from sexist attacks. For still others, we may encourage a young woman or nonbinary student to run for office or maybe we may even run ourselves. Each and every one of us has an obligation to more fully incorporate intersectional civic education into our departments, our universities and our classrooms. We have an obligation to become more involved in our communities. We challenge you to take some time during this conference to think about how you can incorporate some of the strategies we talked about into your classrooms or your institutions.

We know that in this room there is a wealth of knowledge and experience and that there are many of you out there more qualified than we to be standing at this podium. We hope that you learn from each other and you leave Albuquerque on Sunday with a renewed focus and commitment to civic education. Our discipline needs you, your communities need you, but most of all our students need you. Thank you. -

\section{NOTES}

The Consortium refers to the Consortium for Inter-Campus SoTL Research, co-founded and co-directed by Elizabeth A. Bennion and J. Cherie Strachan. With approximately 200 member campuses, the Consortium facilitates multi-campus data collection for political science pedagogy and civic engagement research projects For an overview of the Consortium's structure and inaugural project, see J. Cherie Strachan and Elizabeth A. Bennion. 2016. "Extending Assessment Beyond Our Own Programs and Campuses: The National Survey of Student Leaders and the Consortium for Inter-Campus SoTL Research". PS, Political Science \& Politics 49 (1): 111-115.

\section{REF E R E N C E S}

Beaumont, Elizabeth. 2013. "Political Learning and Democratic Capacities, Some Challenges and Evidence of Promising Approaches." In Alison Rios Millet McCartney, Elizabeth A. Bennion, and Dick Simpson, eds. Teaching Civic Engagement, From Student to Active Citizen. Washington, DC: American Political Science Association.

Bennion, Elizabeth A., Alison Rios Millet McCartney, and Dick Simpson, eds. 2013. Teaching Civic Engagement: From Student to Active Citizen. Washington, DC: American Political Science Association.

Bennion, Elizabeth A., Alison Rios Millet McCartney, and Dick Simpson, eds. 2017. Teaching Civic Engagement: From Student to Active Citizen, and edition. Washington, DC: American Political Science Association.

Campbell, David E. 2010. Why We Vote: How Schools and Communities Shape Our Civic Life. Princeton, NJ: Princeton University Press.

Colby, Anne, Elizabeth Beaumont, Thomas Ehrlich, and Josh Corngold. 2007. Educating for Democracy: Preparing Undergraduates for Responsible Political Engagement. San Francisco, CA: Jossey-Bass.

Collins, Patricia Hill. 200o. Black Feminist Thought: Knowledge, Consciousness, and the Politics of Empowerment. New York: Routledge.

Collins, Patricia Hill. 2004. Black Sexual Politics, African Americans, Gender, and the New Racism. New York: Routledge.

Davidson, Cathy. 2019. "Why We Need a New Liberal Education: We have a responsibility to the next generation of students." Association of American Colleges \& Universities. Available at https://www. aacu.org/liberaleducation/2019/spring/davidson.

Foa, Roberto Stefan and Yascha Mounk. 2017. "The Signs of Deconsolidation." Journal of Democracy $28(1): 5^{-15}$.

Frederick, Angela. 2014. "'Who Better to Do It Than Me!:' Race, Gender \& the Deciding to Run Accounts of Political Women in Texas." Qualitative Sociology 37: 301-321.

Harris Perry, Melissa V. 2011. Sister Citizen: Shame, Stereotypes, and Black Women in America. New Haven, CT: Yale University Press.

Hersh, Eitan. 2019. "College Educated Voters are Ruining American Politics". The Atlantic. Available at https://www. theatlantic.com/ideas/archive/2020/01/ political-hobbyists-are-ruining-politics/605212/.

Hess, Diana E., and Paula McAvoy. 2015. The Political Classroom, Evidence and Ethics in Democratic Education. New York: Routledge.

Karpowitz, Christopher F., and Tali Mendelberg. 2014 The Silent Sex, Gender Deliberation, and Institutions. Princeton, NJ: Princeton University Press.

Marion Young, Iris. 200o. Inclusion and Democracy. New York: Oxford University Press; and Lynn M. Sanders. 1997. "Against Deliberation." Political Theory 25 (3): 347-376.

Mounk, Yascha, and Roberto Stefan Foa. 2020. "This Is How Democracy Dies." The Atlantic. Available at https://www.theatlantic.com/ideas/ archive/2020/01/confidence-democracy-lowestpoint-record/605686/.

Poloni-Staudinger, Lori, and Michael Wolf. 2019. American Difference: A Guide to American Politics in Comparative Perspective. Washington, DC: Sage CQ Press.

Schneider, Monica, Angie Bos, Elizabeth A. Bennion, and J. Cherie Strachan. 2020. "Rude Politics and College Student Engagement.” Southern Political Science Association, January, San Juan, Puerto Rico.

Strachan, J. Cherie, and Mary Senter. 2013. "Student Organizations and Civic Education on Campus: The Greek System.” In Elizabeth A. Bennion, Alison Rios Millet McCartney, and Dick Simpson, eds. Teaching Civic Engagement: From Student to Active Citizen. Washington, DC: American Political Science Association

Strachan, J. Cherie. 2017. “Deliberative Pedagogy's Feminist Potential: Teaching our Students to Cultivate a More Inclusive Public Sphere." In Nicholas V. Longo, Timothy J. Schaffer, and Maxine Thomas, eds. Deliberative Pedagogy and Democratic Engagement: Making Teaching and Learning in Higher Education Relevant to the Adaptive Challenges of our Communities. East Lansing, MI: Michigan State University Press.

Strachan, J. Cherie, Lori Poloni-Staudinger, Shannon Jenkins, and Candice Ortbals-Wiser. 2019. Why Don't Women Rule the World? Understanding Women's Civic and Political Choices. Washington, DC: Sage CQ Press. 